\title{
An effective minimal invasive method in pilonidal sinus surgery: Sinusotomy
}

\section{Pilonidal sinüs cerrahisinde etkin minimal invaziv bir yöntem: Sinüsotomi}

\author{
Önder Karabay ${ }^{1}$
}

\begin{abstract}
Aim: Pilonidal sinus is a common disease. Postoperative pain, limitation of movement, return to daily routine and recurrence are major problems. The aim of this study was to evaluate the postoperative outcomes of patient operated with sinusotomy for pilonidal sinus disease.

Methods: This study was performed retrospectively between 2016 and 2019 in patients treated with sinusotomy for pilonidal sinus disease. Data of 83 patients who underwent sinusotomy were reviewed with hospital records. Age, sex, symptom duration, pit count, operation time, postoperative 2nd day VAS pain score and recurrence rates were evaluated.

Results: 78 (94\%) patients were male and $5(6 \%)$ were female. The mean age was $26.6(15-42)$ years and the mean symptom duration was 4.6 (1-20) months. Mean pit count was 3.2 (1-13), mean operative time was 9.1(5 21) minutes, mean VAS pain score was $0.6(0-2)$ on the second day. Mean healing time was 4.01 (2-11) weeks. Recurrence was observed in 2 patients $(2.4 \%)$.

Conclusion: Sinusotomy is a safe and effective minimally invasive method that may be used in pilonidal sinus surgery. However, comparative prospective studies with other techniques are needed.
\end{abstract}

Key words: Pilonidal sinus disease, surgery, sinusotomy.

Öz

Amaç: Pilonidal sinüs sık karşılaşılan bir hastalıktır. Cerrahi sonrası ağrı, hareket kısıtllılı̆ı̆, günlük işe dönüş ve rekürrens önemli sorunlardır. Bu çalışmanın amacı, pilonidal sinüs hastalığı nedeniyle sinüsotomi yöntemi ile ameliyat edilen hastalarda ameliyat sonrası sonuçlarını değerlendirmektir.

Yöntemler: Bu çalışma, 2016 ve 2019 yılları arasında pilonidal sinüs hastalığı nedeniyle sinüsotomi metodu ile tedavi edilen hastalarda retrospektif olarak yapıldı. Sinüsotomi yapılan 83 hastanın verileri hastane kayıtları ile gözden geçirildi. Yaş, cinsiyet, semptom süresi, pit sayısı, ameliyat süresi, ameliyat sonrası 2.gün VAS ağrı skoru ve rekürrens oranları incelendi.

Bulgular: Hastaların 78'i (94\%) erkek, 5’i (6\%) kadındı. Ortalama yaş 26,6 (15-42) yıl ve ortalama semptom süresi 4.6 (1-20) aydı. Ortalama pit sayısı 3.2 (1-13), ortalama ameliyat süresi 9.1(5-21) dakika, 2.gün ortalam VAS ağrı skoru $0.6(0-2)$ idi. Ortalama iyileşme süresi $4.01(2-11)$ haftaydı. 2 hastada $(2,4 \%)$ rekürrens izlendi. Sonuç: Sinusotomi, pilonidal sinus cerrrahisinde kullanılabilecek güvenli ve etkin bir minimal invaziv yöntem olabilir. Bununla beraber, diğer tekniklerle karşılaştırmalı prospektif çalışmalara ihtiyaç vardır.

Anahtar Kelimeler: Pilonidal sinüs hastalı̆̆ı, cerrahi, sinüsotomi.
${ }^{1}$ Yedikule Surp Pirgic Armenian Hospital General Surgery Department, Istanbul, Turkey.

\section{id}

OK: 0000-0002-3797-0102

Ethics Committee Approval: The study wass approved by the local ethical authority (No. 2019/783).

Etik Kurul Onayı: Çalışma lokal etik komite tarafindan onaylanmıştır (No. 2019/783)

Conflict of Interest: No conflict of interest was declared by the authors.

Çıkar Çatışması: Yazarlar çıkar çatışması bildirmemişlerdir

Financial Disclosure: The authors declared that thi study has received no financial support.

Finansal Destek: Yazarlar bu çalıșma için finansal destek almadıklarını beyan etmişlerdir.

Gelis Tarihi / Received: 15.10 .2019

Kabul Tarihi / Accepted: 07.11.2019

Yayın Tarihi / Published: 01.12.2019

Sorumlu yazar / Corresponding author:

Önder Karabay

Adres/Address: Yedikule Surp Pirgic Armenian Hospital General Surgery Department Kazlicesme Mahallesi Zakirbasi Sokak No:32 Zeytinburnu, Istanbul, Turkey.

e-posta: onderkarabay@gmail.com Tel/Phone: +90 5057330343

Copyright $\odot$ ACEM 


\section{Introduction}

Pilonidal sinus disease (PSD), which is one of the most common surgical diseases in daily practice, affects especially the young population. The etiology of PSD is not yet fully elucidated, however, the most important cause is believed to be fallen hairs accumulating within skin folds and implanting within the skin. The skin becomes more prone to maceration, sweating and bacterial contamination, which facilitates implantation of fallen hairs, creating the necessary conditions for development of the disease [1]. Although it is frequently seen in the sacrococcygeal region, it can also be seen in the fingers, breast skin and umbilicus. The treatment includes open excision, primary closure and flap techniques after surgical excision. However, there is no technique with a greatest efficacy without recurrence. Especially in open techniques, the wound healing time is long and pain is more in stitched techniques. Another disadvantage is the late return to daily activities.

Therefore, new techniques have been investigated today. In recent years, with the development of technology, techniques such as tract ablation with laser and endoscopic curettage have emerged. In addition, less invasive procedures with minor excisions are also on the agenda [2]. One of these techniques is sinusotomy. With this technique, it is aimed to increase postoperative comfort by making operation in a smaller area and return to daily life early. It is seen in the literature that there is not enough research on this subject.

The aim of this retrospective study was to investigate the postoperative outcomes of patients undergoing sinusotomy technique for sacrococcygeal pilonidal sinus (SPS).

\section{Material and methods}

The files of patients who underwent sinusotomy surgery for SPS by a single surgeon in a private hospital between January 2016 and August 2019 were retrospectively reviewed. Informed consent was obtained from all patients. Institutional review board approval was obtained (Yedikule Surp Pirgic Armenian Hospital, Istanbul, Turkey; approval number: 2019/783). The study was performed in accordance with the Declaration of Helsinki.

There were totally 91 patients with SPS surgery. Five (5.5\%) patients who had pilonidal sinus abscess and three $(3.2 \%)$ patients who requested another technique were excluded. $83(91.3 \%)$ patients with sinusotomy were included to the study (Figure 1). The patients were evaluated in terms of age, sex, symptom duration, and pit count in the disease area, operation time, and length of hospital stay, postoperative VAS (Visual Analog Scale) pain score and recurrence rate. In the preoperative evaluation, sinus mouths (pits) in the disease area were counted and noted. Antibiotic treatment was given to the patients with infection until surgery and then prepared for surgery. All patients were operated with local anesthesia and sedation in Jack knife position. Diluted bupivacain (Marcain, AstraZeneca, England) and isotonic $0,9 \% \mathrm{NaCl}$ solution in a 1: 1 ratio was used for local anesthesia. All patients were discharged on the same day with surgery. On the postoperative second day, operation area was controlled and the pain was evaluated with VAS. Patients were checked once a week until recovery was completed. The closure of the open wound with the epidermis was accepted as complete recovery. All patients were asked whether they did their daily routine at each check-up. Patients were followed for 6 months for recurrence.

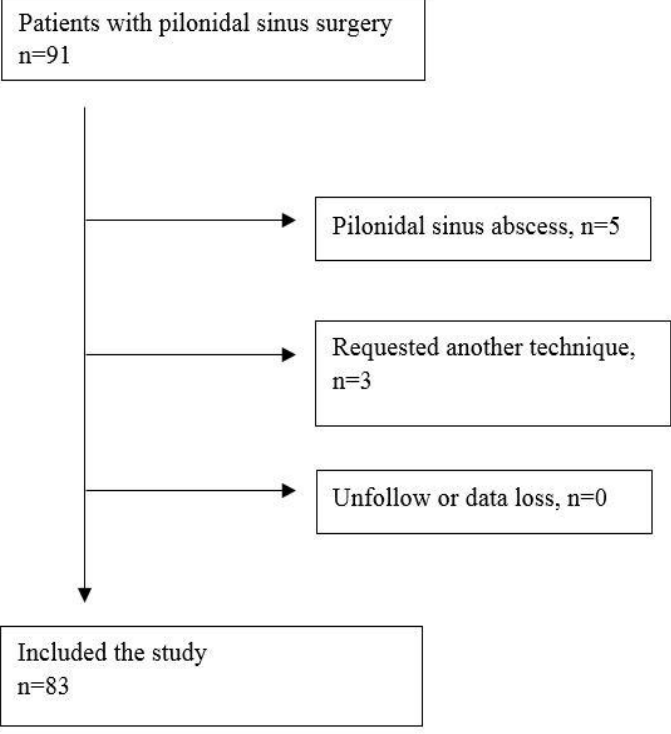

Figure 1. Flowchart of the study.

\section{Surgical technique}

In the jack knife position, the pilonidal sinus area and pits in the sacrum were determined. Each pit was inserted through a thin clamp or stylet to reveal sinus tracts. The skin on the tract was excised and the base was curetted (Figures 2 and 3). The wound was closed with wet dressing.

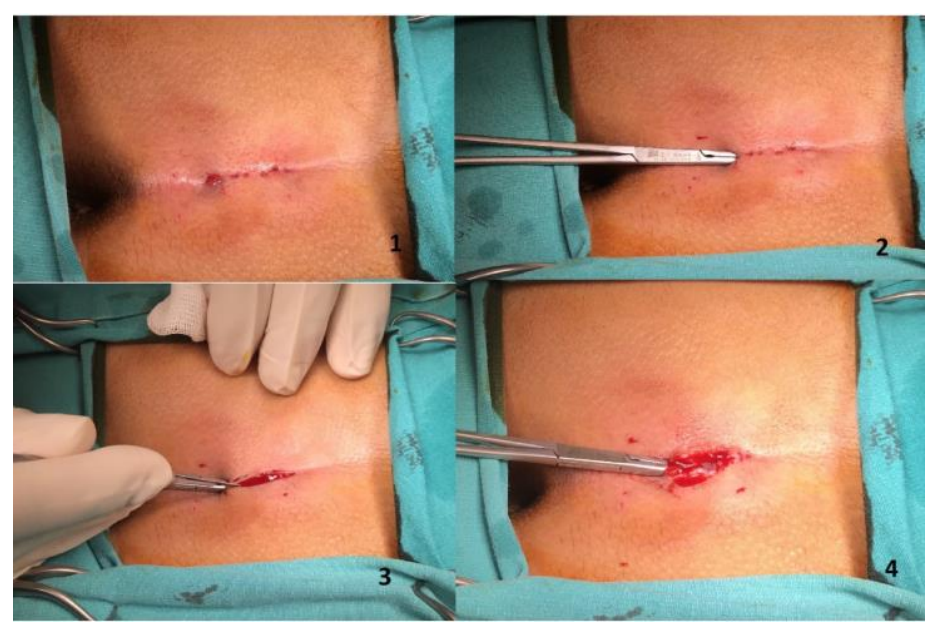

Figure 2. Stages of the surgical technique. 1. Appearance of the pits, 2. Determination of the sinus tract with a clamp, 3. Opening of the tract, 4.View of the sinus content.

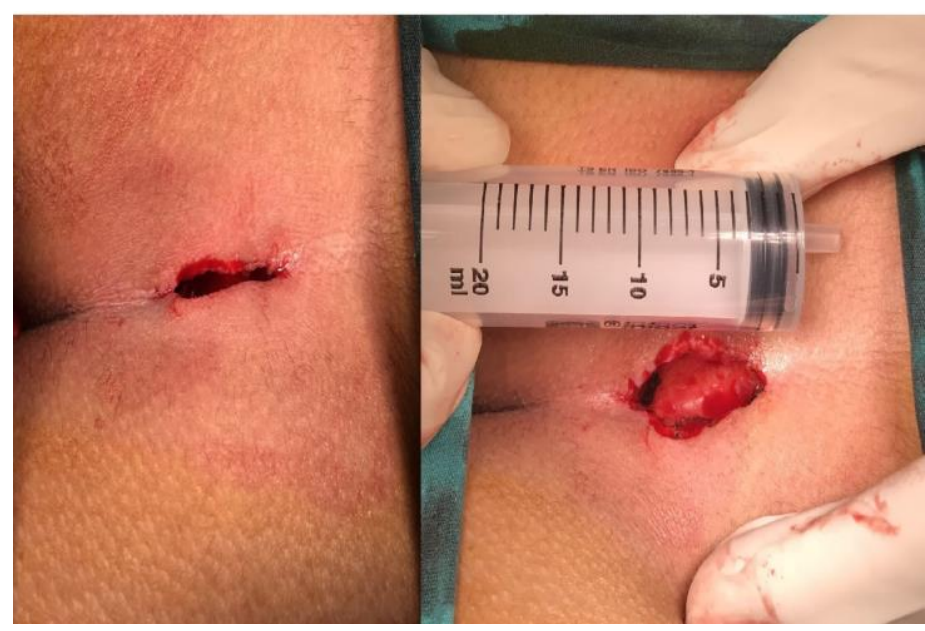

Figure 3. Postoperative appearance. 


\section{Results}

A total of 91 patients who were diagnosed with PSD and who underwent surgical treatment in a private hospital between January 2016 and June 2019 were included in this retrospective study. Five $(5.5 \%)$ patients who underwent surgery for pilonidal sinus abscess and three (3.2\%) patients who underwent voluntary Limberg flap surgery were excluded. A total of $83(91.3 \%)$ patients were examined. $78(94 \%)$ of the patients were male and $5(6 \%)$ were female. The mean age was $26.6(15-42)$ years and the mean symptom duration was $4.6(1-$ 20) months. The mean pit count was 3.2 (1-13) and the mean operation time was 9.1(5-21) minutes. All patients were discharged on the same day. There were no complications on peroperative and postoperative period. The postoperative VAS score was $0.6(0-2)$ on the second postoperative day. It was observed that all patients were able to return to daily routine at the first week. Mean healing time was 4.04 (2-11) weeks. Recurrence was observed in $2(2.4 \%)$ patients (Table). These patients were operated with the same technique and complete recovery was observed.

Table. Demographic features of patients.

\begin{tabular}{lc} 
& $\mathrm{N}($ range) \\
\hline Age (year) & $26.6(15-42)$ \\
Sex (male/female) & $78 / 5$ \\
Mean symptom duration (month) & $4.6(1-20)$ \\
Pit count (n) & $3.2(1-13)$ \\
Operation time (minute) & $9.1(5-21)$ \\
VAS pain score & $0.6(0-2)$ \\
Healing time (week) & $4(2-11)$ \\
Recurrence & $2(2.4 \%)$
\end{tabular}

\section{Discussion}

Intergluteal sulcus is the most common site of the disease with different nomenclature called pilonidal cyst, pilonidal sinus or cyst dermoid sacral. Patients usually present with pain and/or discharge of infection. Although, it is more common especially in people who sit long time. It is mentioned as driver's disease, not only in our country but also in other countries [3]. SPS usually seems in the young population. For this reason, it has been sought in methods that return to work is faster and postoperative comfort is more important in its treatment. Although SPS is widespread in our country, there is still no gold standard treatment method in its treatment. However, since most of the treatments involve major resections, postoperative pain and return to daily life may be a problem. Many patients may therefore delay treatment.

Excision and primary closure method, which is one of the most commonly used methods in treatment, is preferred quite frequently due to its technical ease and rapid application. In the study performed by Kartal et al. [4] with 634 patients, primary closure and flap methods were compared. The mean operation time in the primary closure group was 26.9 minutes and the mean hospital stay was 1.7 days [4]. Comparing Limberg flap and Karydakis flap techniques, Alvandipour et al. [3] found that mean operative time was 29.1 and 23 minutes, and mean hospitalization time was 1.4 days. Karaca et al. [5] likewise compared the flap methods and found that the mean length of hospital stay was 1.1 days. In the study by Oliveira et al. [6], minimally invasive methods (MIT) (endoscopic treatment and pit-picking) were compared with primary closure and the mean operative time was 36.1 and 48.7 minutes, respectively.
When the primary closure and flap techniques are used frequently, the mean length of hospitalization is at least 1.1 days and it is longer than the results in our study. In this technique, patients can be discharged home on the same day after surgery. Similarly, the duration of surgery was found to be 9.1 minutes in our study and was shorter than excision and closure techniques. Especially flap techniques often require spinal and general anesthesia, while microinvasive procedures are usually performed with local anesthesia and sedation support. This causes shorter hospital stay and shorter operation time. Therefore, sinusotomy is often performed as an outpatient procedure.

Another important issue in the treatment of SPS is postoperative pain. In the study of Oliveira et al. [6], when the primary closure and MIT were compared, the number of painful days after MIT was zero. In the Alvandipour et al [3] study, pain with sitting after Limberg and Karydakis flap operations was questioned and VAS score was 4 and 4.1, respectively. In this study, pain was questioned on postoperative 2 nd day and the mean VAS score was 0.6. Similarly, patients were able to return to their daily lives from day 1 . We think that this is caused by minimal excision and not using any suture material.

Recurrence is perhaps the most undesirable outcome of the disease. Therefore, this is the most researched issue. In the Alvandipour et al. [3] study, the recurrence rate after limberg and karydakis flap was 0 and $2.7 \%$, respectively. In the study of Bessa et al. [7], Karydakis and Limberg flaps were compared and recurrence was 3 and $2 \%$. In the Kartal et al. [4] study, recurrence rates were found to be $3.8 \%$ in Limberg flap, $2.1 \%$ in Karydakis flap, and $11.4 \%$ in primary closure. Rabie et al. [8] found the lowest recurrence rate $(12.5 \%)$ in sinusotomy group in a comparative study. In our study, recurrence was observed in 2 (2.4\%) patients, who were retreated with the same technique and showed complete recovery. Especially in flap techniques, seroma and wound infections under the tissue cause recurrence. In open techniques, such complications are less common as the fluid accumulated outside the wound flows. In open techniques, if the skin closes before the healing of the wound base, recurrence develops. For this reason, we recommend wound care with daily shower for open wound care.

The disadvantage of the technique is that the wound closes in a long time. Depending on the size of the wound, complete closure can sometimes take up to 2 months. In our study, mean healing time was 4.04 (2-11) weeks. Al Naami et al. [9] found over 2 months healing time in $10 \%$ patients.

Limitations of this study were retrospective, single surgeon and single center, no comparison and no long-term results. Better results can be obtained with a comparative study with prospective and other techniques.

In conclusion, we believe that sinusotomy may be a safe and feasible method in the treatment of SPS because of its high postoperative comfort and comparable recurrence rate compared to other techniques.

\section{References}

1. Kose E, Hasbahceci M, Tonyali H, Karagulle M. Comparative analysis of the same technique-the same surgeon approach in the surgical treatment of pilonidal sinus disease: a retrospective cohort study. Ann Surg Treat Res. 2017,93:82-7.

2. Velotti N, Manlgrasso M, Lauro KD, Aralmo E, Calculli F, Vertaldi S, et al. Minimally invasive pilonidal sinus treatment: A narrative review. Open Med. 2019;532-6.

3. Alvandipour M, Zamani MS, Ghorbani M, Charati JY, Karami MY. Ann Coloproctol 2019 May 22. https://doi.org/10.3393/ac.2018.09.27

4. Kartal A, Aydin HO, Oduncu M, Ferhatoglu MF, Kivilcim T, Filiz AI. Comparison of three surgical techniques in pilonidal sinus surgery. Prague Med Rep. 2018;4:148-55. 
5. Karaca $\mathrm{T}$, Yoldaş $\mathrm{O}$, Bilgin $\mathrm{BC}$, Ozer S, Yoldaş S, Karaca NG. Comparison of short-term results of modified Karydakis flap and modified Limberg flap for pilonidal sinus surgery. Int J Surg. 2012;10:601-6.

6. OliveiraAI, Barasso C, Osorio A, Pinto JC. Minimally invasive surgical treatment of pilonidal disease: Mid-term retrospective analysis of a single center. Front Pediatr. 2019;7:1-6.

7. Bessa SS. Comparison of short-term results between the modified Karydakis flap and the modified Limberg flap in the management of pilonidal sinus disease: a randomized controlled study. Dis Colon Rectum. 2013;56:491-8.

8. Rabie ME, Refeidi AA, Haizaee A, Hilal S, Ajmi H, Amri AA Sacrococcygeal pilonidal disease: sinotomy versus excisional surgery, a retrospective study. ANZ J Surg. 2007;77:177-80.

9. Al-Naami MY. Outpatient pilonidal sinotomy complemented with good wound and surrounding skin care. Saudi Med J. 2005;26:285-8. 